\title{
Cyclometalated Iridium Complexes as Highly Active Catalysts for the Hydro- genation of Imines
}

Weijun Tang, Chunho Lau, Xiaofeng Wu, Jianliang Xiao*

Department of Chemistry, University of Liverpool, Liverpool, L69 7ZD, UK

Fax +44(151)7943588; E-mail: j.xiao@liv.ac.uk

Received: 20.08.2013; Accepted after revision: 04.10.2013

Abstract: A robust cyclometalated iridium catalyst has been developed for highly effective hydrogenation of imines. With very low catalyst loading (down to $0.005 \%$ ), good to excellent yields have been achieved for a range of substrates in a short reaction time under mild conditions, providing an easy, efficient protocol for making amines.

Key words: cyclometalated complexes, hydrogenation, imines, iridium, iridicycles

Amines are important building blocks for the synthesis of numerous pharmaceutical and agrochemical substances. ${ }^{1}$ Among the various methods of synthesising amines, including stoichiometric boron hydride and organocatalytic reduction of $\mathrm{C}=\mathrm{N}$ double bonds, transition-metal-catalysed hydrogenation of imines is one of the most convenient and efficient. ${ }^{2,3}$ Although significant progress has been achieved in this area, highly efficient reduction of $\mathrm{C}=\mathrm{N}$ double bonds is still challenging. Recently, our group ${ }^{4}$ and other groups ${ }^{5,6}$ have explored a series of cyclometalated iridium compounds, some of which have been successfully applied to transfer hydrogenation of imines and reductive amination of ketones. More recently, we have found that these iridicycles allow for efficient hydrogenation of imines ${ }^{4 \mathrm{f}}$ as well as N-heterocycles. ${ }^{4 \mathrm{~g}}$ Herein,

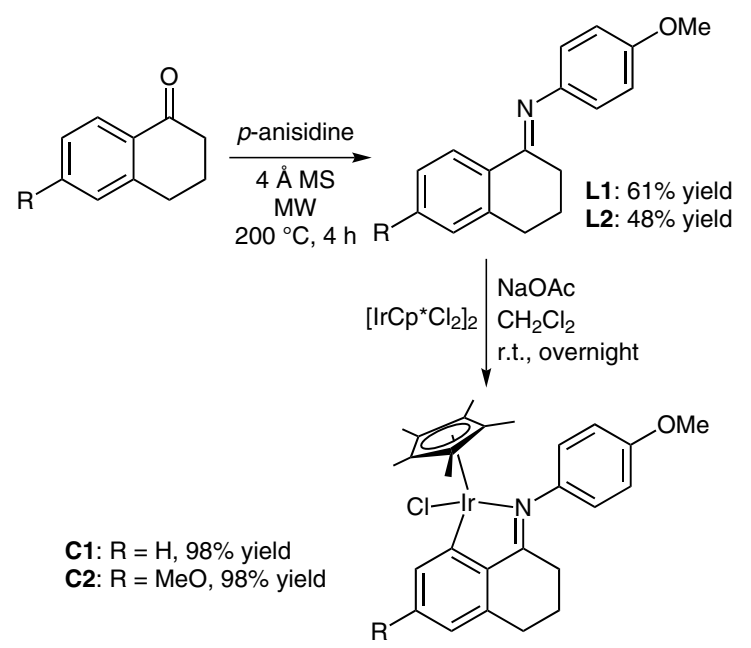

Scheme 1 Synthesis of the cyclometalated iridium complexes $\mathbf{C 1}$ and $\mathbf{C 2}$

SYNLETT 2014, 25, 0081-0084

Advanced online publication: 06.11.2013

DOI: 10.1055/s-0033-1340086; Art ID: ST-2013-D0797-L

C Georg Thieme Verlag Stuttgart · New York we report a tailor-made, more robust iridicycle, which catalyses the hydrogenation of imines with hydrogen gas under low catalyst loading.

We started with preparation of the cyclometalated iridium complexes. Using procedures reported previously, ${ }^{4-6}$ two new cyclometalated iridium complexes were synthesised readily from tetralone and its derivative in two steps (Scheme 1). With the imino carbon being embedded in a ring, the resulting iridicycles $\mathbf{C 1}$ and $\mathbf{C 2}$ were expected to be more robust in comparison with those reported before. ${ }^{4}$

Table 1 Screening of Conditions for the Hydrogenation of Imine $1 \mathbf{a}^{\mathrm{a}}$<smiles>COc1ccc(N=C(C)c2ccccc2)cc1</smiles>

\begin{tabular}{|c|c|c|c|c|c|}
\hline Entry & Cat. & $\mathrm{S} / \mathrm{C}$ ratio & Solvent & $\begin{array}{l}\text { Temp } \\
\left({ }^{\circ} \mathrm{C}\right)\end{array}$ & $\begin{array}{l}\text { Yield } \\
(\%)^{b}\end{array}$ \\
\hline 1 & $\mathrm{C} 1$ or $\mathbf{C 2}$ & 5000 & $\mathrm{CH}_{2} \mathrm{Cl}_{2}$ & 40 & NO \\
\hline 2 & $\mathbf{C} 1$ or $\mathbf{C 2}$ & 5000 & THF & 40 & $\mathrm{NO}$ \\
\hline 3 & $\mathbf{C} 1$ or $\mathbf{C 2}$ & 5000 & toluene & 40 & $\mathrm{NO}$ \\
\hline 4 & $\mathbf{C} 1$ or $\mathbf{C 2}$ & 5000 & $\mathrm{EtOH}$ & 40 & $<2$ \\
\hline 5 & $\mathbf{C} 1$ or $\mathbf{C 2}$ & 5000 & $\mathrm{Et}_{2} \mathrm{O}$ & 40 & $\mathrm{NO}$ \\
\hline 6 & $\mathrm{C} 1$ & 5000 & TFE & 40 & 20 \\
\hline 7 & $\mathrm{C} 2$ & 5000 & TFE & 40 & 10 \\
\hline $8^{c}$ & C1 & 5000 & toluene & 40 & 19 \\
\hline 9 & $\mathrm{C} 1$ & 5000 & TFE & 85 & 93 \\
\hline $10^{\mathrm{c}}$ & C1 & 5000 & toluene & 85 & 93 \\
\hline $11^{\mathrm{d}}$ & $\mathrm{C} 1$ & 10000 & TFE & 85 & 90 \\
\hline $12^{\mathrm{e}}$ & $\mathrm{C} 1$ & 20000 & TFE & 85 & 86 \\
\hline
\end{tabular}

${ }^{a}$ The reaction was carried out with $\mathbf{1 a}(0.15 \mathrm{mmol}), \mathbf{C 1}$ or $\mathbf{C 2}(0.02$ $0.005 \mathrm{~mol} \%)$, solvent $(0.7 \mathrm{~mL})$, in reaction time of $1 \mathrm{~h}$, at initial $\mathrm{H}_{2}$ pressure of 20 bar.

${ }^{\mathrm{b}}$ The yield was determined by ${ }^{1} \mathrm{H}$ NMR with an internal standard (1,3,5-trimethoxybenzene); $\mathrm{NO}=$ no reaction observed.

${ }^{c} \mathrm{NaBARF}$ ( 2 equiv) was added.

${ }^{\mathrm{d}}$ Amount of $1 \mathrm{a}$ used was $0.3 \mathrm{mmol}$.

e Amount of 1a used was $0.6 \mathrm{mmol}$, and the reaction time was $2 \mathrm{~h}$. 
Having obtained these precatalysts, the hydrogenation of ketoimine 1a was then examined. The reduction was carried out at a high substrate to catalyst $(\mathrm{S} / \mathrm{C})$ ratio of 5000 with 20 bar initial hydrogen pressure at $40{ }^{\circ} \mathrm{C}$. As shown in Table 1, little reaction was observed with both of the catalysts in either polar or nonpolar common organic solvents, such as $\mathrm{CH}_{2} \mathrm{Cl}_{2}$, THF, toluene, EtOH, and $\mathrm{Et}_{2} \mathrm{O}$ (Table 1, entries 1-5). However, to our satisfaction, some conversion was obtained for the reduction by using trifluoroethanol (TFE) as solvent (Table 1, entries 6 and 7). This is probably due to the dissociation and/or solvation of the chloride ion of the catalyst by the strongly ionising TFE. $^{7}$ This significant solvent effect has been noted in our previous studies. ${ }^{4 f, g}$ Indeed, promoting the dissociation of chloride with NaBARF makes the reaction work in the nonpolar toluene (Table 1, entry 8 ). Full conversion was obtained with $\mathbf{C 1}$ at a high temperature of $85^{\circ} \mathrm{C}$ (Table 1, entries 9 and 10). The hydrogenation reaction proceeded well at even a higher $\mathrm{S} / \mathrm{C}$ ratio of 20000 in TFE (Table 1, entries 11 and 12). The screening indicates that $\mathbf{C 1}$ is more active than $\mathbf{C 2}$ (Table 1, entries 6 and 7).

With the optimal reaction conditions in hand, the scope of substrates was explored subsequently with $\mathbf{C 1}$ and the results are listed in Table 2. In general, most of the imines were fully hydrogenated at a high $\mathrm{S} / \mathrm{C}$ ratio of 10000 , affording good to excellent isolated yields. However, a significant electronic effect arising from the substituents on the aryl rings of the substrates was observed, with electron-donating groups favouring hydrogenation. Thus excellent yields were obtained for imines with methyl and methoxy groups on the aryl rings (Table 2, entries 1-7). However, for substrates with electron-withdrawing substituents on the aryl rings, good yields could only be obtained at a higher catalyst loading (Table 2, entries 10 12). For weakly electron-withdrawing substituents (e.g., $\mathrm{Cl}$ on one aryl ring), a good yield was afforded under the standard conditions (Table 2, entries 8 and 9). It is worth noting that the hydrogenation can be readily scaled up. Thus, 1a was fully converted on a two-gram scale into the desired amine product in two hours under the optimised conditions, affording 93\% isolated yield.

In summary, we have synthesised a new type of robust cyclometalated iridium catalysts, and the catalyst has been shown to be effective for the hydrogenation of imines at high $\mathrm{S} / \mathrm{C}$ ratios under mild conditions. ${ }^{8}$ The high activity, air-stability and ease of preparation make the catalyst attractive for imine hydrogenation and possibly for other reactions as well.

\section{Acknowledgment}

We thank EPSRC for a postdoctoral fellowship (W.J.T.) and the University of Liverpool for funding (X.F.W.). Thanks also go to the EPSRC UK National Mass Spectrometry Facility at Swansea University for mass analysis.
Table 2 Hydrogenation of Imines with $\mathbf{C 1}^{\mathrm{a}}$

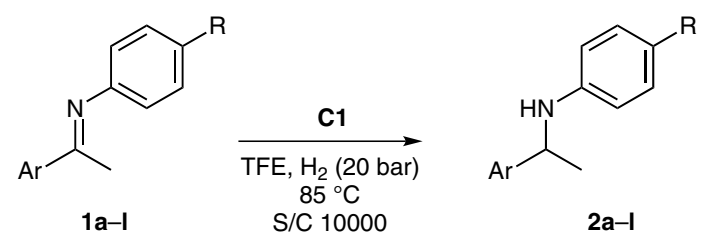

\begin{tabular}{lll}
\hline Entry Substrate Product & $\begin{array}{l}\text { Yield } \\
(\%)^{\mathrm{b}}\end{array}$ \\
\end{tabular}

2<smiles>COc1ccc(NC(C)c2ccccc2)cc1</smiles>

$1 \mathrm{c}$<smiles>COc1ccc(NC(C)c2ccc(C)cc2)cc1</smiles><smiles>COc1ccc(NC(C)c2cccc(C)c2)cc1</smiles><smiles>COc1ccc(NC(C)c2ccccc2C)cc1</smiles>

1e<smiles>COc1ccc(NC(C)c2ccc(OC)cc2)cc1</smiles> 
Table 2 Hydrogenation of Imines with $\mathbf{C 1}^{\mathrm{a}}$ (continued)<smiles>[R]c1ccc(N=C(C)[Al])cc1</smiles>

\begin{tabular}{ll}
\hline Entry Substrate Product & $\begin{array}{l}\text { Yield } \\
(\%)^{\mathrm{b}}\end{array}$ \\
\hline
\end{tabular}

8

$1 \mathrm{~h}$<smiles>COc1ccc(NC(C)c2ccc3ccccc3c2)cc1</smiles>

9

$1 \mathbf{i}$<smiles>COc1ccc(NC(C)c2ccc(Cl)cc2)cc1</smiles>

10

$\mathbf{1 j}$<smiles>COc1ccc(NC(C)c2ccc(Br)cc2)cc1</smiles><smiles>CC(Nc1ccc(Br)cc1)c1ccccc1</smiles>

12<smiles>COc1ccc(NC(C)c2ccc([N+](=O)[O-])cc2)cc1</smiles>

11
${ }^{a}$ The reaction was carried out with imine $(0.3 \mathrm{mmol}), \mathbf{C 1}(0.01$ mol\%), solvent $(0.7 \mathrm{~mL})$, in reaction time of $1 \mathrm{~h}$, at initial $\mathrm{H}_{2}$ pressure of 20 bar.

${ }^{\mathrm{b}}$ Isolated yield.

${ }^{\mathrm{c}}$ Amount of $\mathbf{C 1}$ used was $0.1 \mathrm{~mol} \%$.

\section{References and Notes}

(1) For reviews, see: (a) Breuer, M.; Ditrich, K.; Habicher, T.; Hauer, B.; Keßeler, M.; Sturmer, R.; Zelinski, T. Angew. Chem. Int. Ed. 2004, 43, 788. (b) Blacker, J.; Martin, J. In Asymmetric Catalysis on Industrial Scale: Challenges, Approaches and Solutions; Blaser, H. U.; Schmidt, E., Eds.; Wiley-VCH: Weinheim, 2004, 201.

(2) For recent reviews, see: (a) Nugent, T. C.; El-Shazly, M. Adv. Synth. Catal. 2010, 352, 753. (b) Xie, J. H.; Zhu, S. F.; Zhou, Q. L. Chem. Soc. Rev. 2012, 41, 4126. (c) Xie, J. H.; Zhu, S. F.; Zhou, Q. L. Chem. Rev. 2011, 111, 1713. (d) Fleury-Bregeot, N.; de la Fuente, V.; Castillon, S.;
Claver, C. ChemCatChem 2010, 2, 1346. (e) Wang, C.; Villa-Marcos, B.; Xiao, J. Chem. Commun. 2011, 47, 9773. (f) Blaser, H.-U.; Spindler, F. In Handbook of Homogeneous Hydrogenation; Vol. 3; de Vries, J. G.; Elsevier, C. J., Eds.; Wiley-VCH: Weinheim, 2007, 1193.

(3) For selected recent examples of hydrogenation of imines, see: (a) Iimuro, A.; Yamaji, K.; Kandula, S.; Nagano, T.; Kita, Y.; Mashima, K. Angew. Chem. Int. Ed. 2013, 52, 2046. (b) Ye, Z. S.; Guo, R. N.; Cai, X. F.; Chen, M. W.; Shi, L.; Zhou, Y. G. Angew. Chem. Int. Ed. 2013, 52, 3685. (c) Ye, Z. S.; Chen, M. W.; Chen, Q. A.; Shi, L.; Duan, Y.; Zhou, Y. G. Angew. Chem. Int. Ed. 2012, 51, 10181. (d) Werkmeister, S.; Fleischer, S.; Zhou, S. L.; Junge, K.; Beller, M. ChemSusChem 2012, 5, 777. (e) Werkmeister, S.; Fleischer, S.; Junge, K.; Beller, M. Chem. Asian J. 2012, 7, 2562. (f) Vaquero, M.; Suarez, A.; Vargas, S.; Bottari, G.; Alvarez, E.; Pizzano, A. Chem. Eur. J. 2012, 18, 15586. (g) Maj, A. M.; Suisse, I.; Meliet, C.; Hardouine, C.; Agbossou-Niedercorn, F. Tetrahedron Lett. 2012, 53, 4747. (h) Hou, C. J.; Wang, Y. H.; Zheng, Z.; Xu, J.; Hu, X. P. Org. Lett. 2012, 14, 3554. (i) Balazsik, K.; Szollosi, G.; Berkesi, O.; Szalontai, G.; Fulop, F.; Bartok, M. Top. Catal. 2012, 55, 880. (j) Arai, N.; Utsumi, N.; Matsumoto, Y.; Murata, K.; Tsutsumi, K.; Ohkuma, T. Adv. Synth. Catal. 2012, 354, 2089. (k) Mrsic, N.; Panella, L. E.; Ijpeij, G.; Minnaard, A. J.; Feringa, B. L.; de Vries, J. G. ChemCatChem 2011, 3, 1139. (l) Chen, F.; Ding, Z. Y.; Qin, J.; Wang, T. L.; He, Y. M.; Fan, Q. H. Org. Lett. 2011, 13, 4348. (m) Chang, M. X.; Li, W.; Zhang, X. M. Angew. Chem. Int. Ed. 2011, 50, 10679. For selected examples of hydrogenation of imines with half-sandwich iridium complexes, see: (n) Li, C. Q.; Xiao, J. L. J. Am. Chem. Soc. 2008, 130, 13208. (o) Li, C. Q.; Wang, C.; Villa-Marcos, B.; Xiao, J. L. J. Am. Chem. Soc. 2008, 130, 14450. (p) Shirai, S.; Nara, H.; Kayaki, Y.; Ikariya, T. Organometallics 2009, 28, 802. (q) Ding, Z. Y.; Chen, F.; Qin, J.; He, Y. M.; Fan, Q. H. Angew. Chem. Int. Ed. 2012, 51, 5706. (r) Li, Z. W.; Wang, T. L.; He, Y. M.; Wang, Z. J.; Fan, Q. H.; Pan, J.; Xu, L. J. Org. Lett. 2008, 22, 5265. (s) Chen, F.; Wang, T. L.; He, Y. M.; Ding, Z. Y.; Li, Z. W.; Xu, L. J.; Fan, Q. H. Chem. Eur. J. 2011, 17, 1109.

(4) (a) Wang, C.; Pettman, A.; Bacsa, J.; Xiao, J. L. Angew. Chem. Int. Ed. 2010, 49, 7548. (b) Barnard, J. H.; Wang, C.; Berry, N. G.; Xiao, J. L. Chem. Sci. 2013, 4, 1234. (c) Wei, Y.; Xue, D.; Lei, Q.; Wang, C.; Xiao, J. L. Green Chem. 2013, 15, 629. (d) Lei, Q.; Wei, Y.; Talwar, D.; Xue, D.; Xiao, J. L. Chem. Eur. J. 2013, 19, 4021. (e) Wei, Y.; Wang, C.; Jiang, X.; Xue, D.; Li, J.; Xiao, J. L. Chem. Commun. 2013, 49, 5408. (f) Villa-Marcos, B.; Tang, W. J.; Wu, X. F.; Xiao, J. L. Org. Biomol. Chem. 2013, 11, 6934. (g) Wu, J. J.; Barnard, J. H.; Zhang, Y.; Talwar, D.; Robertson, C. M.; Xiao, J. L. Chem. Commun. 2013, 49, 7052.

(5) Davies, D. L.; Al-Duaij, O.; Fawcett, J.; Giardiello, M.; Hilton, S. T.; Russell, D. R. Dalton Trans. 2003, 4132.

(6) (a) Schramm, Y.; Barrios-Landeros, F.; Pfaltz, A. Chem. Sci. 2013, 4, 2760. (b) Djukic, J. P.; Iali, W.; Pfeffer, M.; Le Goff, X. F. Chem. Eur. J. 2012, 18, 6063. (c) Jerphagnon, T.; Haak, R.; Berthiol, F.; Gayet, A. J. A.; Ritleng, V.; Holuigue, A.; Pannetier, N.; Pfeffer, M.; Voelklin, A.; Lefort, L.; Verzijl, G.; Tarabiono, C.; Janssen, D. B.; Minnaard, A. J.; Feringa, B. L.; de Vries, J. G. Top. Catal. 2010, 53, 1002.

(7) Eberson, L.; Hartshorn, M. P.; Persson, O.; Radner, F. Chem. Commun. 1996, 2105.

(8) General Procedure for the Synthesis of the Cyclometalated Iridium Complexes: An oven-dried Schlenk tube containing a magnetic stirrer bar was charged with $\left[\mathrm{Cp}^{*} \mathrm{IrCl}_{2}\right]_{2}$ (1 equiv), imine ligand ${ }^{5}$ ( 2 equiv) and $\mathrm{NaOAc}\left(10\right.$ equiv). Following degassing with $\mathrm{N}_{2}(3 \times)$, 
freshly distilled $\mathrm{CH}_{2} \mathrm{Cl}_{2}$ was injected. The resulting mixture was stirred at r.t. overnight. The reaction mixture was then filtered through Celite ${ }^{\circledR}$, washed with $\mathrm{CH}_{2} \mathrm{Cl}_{2}$ and the combined organic solvents were concentrated in vacuo. The resulting solid was washed with $\mathrm{Et}_{2} \mathrm{O}$-hexane and recrystallised from $\mathrm{CH}_{2} \mathrm{Cl}_{2}$-hexane.

C1: orange powder (90.5 mg, 98\%). ${ }^{1} \mathrm{H}$ NMR (400 MHz, $\left.\mathrm{CDCl}_{3} ; 258 \mathrm{~K}\right): \delta=7.79(\mathrm{br}, 1 \mathrm{H}), 7.62-7.64(\mathrm{~d}, J=7.6 \mathrm{~Hz}$, $1 \mathrm{H}), 7.12-7.16(\mathrm{~m}, 1 \mathrm{H}), 6.92-6.99(\mathrm{~m}, 3 \mathrm{H}), 6.76-6.78(\mathrm{~d}$, $J=7.2 \mathrm{~Hz}, 1 \mathrm{H}), 3.85(\mathrm{~s}, 3 \mathrm{H}), 2.63-2.97$ (m, $4 \mathrm{H}), 1.87-1.88$ (m, $2 \mathrm{H}), 1.43(\mathrm{~s}, 15 \mathrm{H}) .{ }^{13} \mathrm{C} \mathrm{NMR}\left(100 \mathrm{MHz}, \mathrm{CDCl}_{3} ; 258\right.$ $\mathrm{K}): \delta=182.9,168.4,157.4,144.6,143.4,143.0,132.7$, 132.4, 125.2, 123.3, 121.2, 115.0, 112.3, 88.9, 55.7, 30.4, 29.2, 23.8, 15.5, 8.9. Anal. Calcd for $\mathrm{C}_{27} \mathrm{H}_{31}$ ClIrNO: C, 52.88; H, 5.10; N, 2.61. Found: C, 52.69; H, 5.12; N, 2.09 . C2: pale orange powder (31.7 mg, 98\%). ${ }^{1} \mathrm{H}$ NMR (400 $\left.\mathrm{MHz}, \mathrm{CDCl}_{3} ; 258 \mathrm{~K}\right): \delta=7.76-7.79(\mathrm{~m}, 1 \mathrm{H}), 7.15-7.16(\mathrm{~d}$, $J=1.6 \mathrm{~Hz}, 1 \mathrm{H}), 6.82-6.93(\mathrm{~m}, 3 \mathrm{H}), 6.33(\mathrm{~s}, 1 \mathrm{H}), 3.86(\mathrm{~s}$, $3 \mathrm{H}), 3.84$ (s, $3 \mathrm{H}), 2.56-2.93$ (m, $4 \mathrm{H}), 1.84-1.85$ (m, $2 \mathrm{H})$, $1.42(\mathrm{~s}, 15 \mathrm{H}) .{ }^{13} \mathrm{C} \mathrm{NMR}\left(100 \mathrm{MHz}, \mathrm{CDCl}_{3}\right): \delta=181.4$,
$170.7,162.3,157.5,144.7,143.5,138.4,124.8,117.6$, 114.2, 113.8, 113.5, 106.9, 88.7, 55.6, 55.0, 30.2, 29.5, 23.9, 8.7. Anal. Calcd for $\mathrm{C}_{28} \mathrm{H}_{33} \mathrm{ClIrNO}_{2}$ : C, 52.28; $\mathrm{H}, 5.17 ; \mathrm{N}$, 2.18. Found: C, 52.43; H, 5.48; N, 1.94 .

Procedure for the Hydrogenation of Imines with Cyclometalated Iridium Complex C1: A glass liner containing a stirrer bar was charged with the requisite imine $(0.3 \mathrm{mmol})$ and TFE $(0.75 \mathrm{~mL})$. The mixture was stirred until the imine was dissolved and catalyst $\mathbf{C 1}$ was then added (10 $\mu \mathrm{L}$ stock solution, made by dissolving $\mathbf{C 1}$ in TFE: 0.03 $\mathrm{mmol} \mathbf{C 1}$ in $10 \mathrm{~mL}$ TFE). The glass liner was then placed into an autoclave followed by degassing with $\mathrm{H}_{2}(3 \times)$. The hydrogenation was carried out at 20 bar $\mathrm{H}_{2}$ with stirring at 85 ${ }^{\circ} \mathrm{C}$ for $1 \mathrm{~h}$. After the reaction was finished, the autoclave was allowed to cool to r.t. The hydrogen gas was then carefully released in the fume hood, the solution transferred to a flask and concentrated in vacuo to afford the crude product. Flash chromatographic purification with a column of silica gel eluted with petroleum ether-EtOAc $(20: 1 \rightarrow 5: 1)$ yielded the desired amine product. 